\title{
Current Status and Perspectives of Forestry Entrepreneurship in Croatia
}

\author{
Mario Šporčić ${ }^{1}$, Matija Landekići ${ }^{1 *}$, Ivica Papa ${ }^{1}$, Kruno Lepoglavec ${ }^{1}$, Hrvoje Nevečerel $^{1}$, Ante Seletković ${ }^{2}$, \\ Matija Bakarić ${ }^{1}$
}

(1) University of Zagreb, Faculty of Forestry, Department of Forest Engineering, Svetošimunska 25, HR-10000 Zagreb, Croatia; (2) University of Zagreb, Faculty of Forestry, Department of Forest Inventory and Management, Svetošimunska 25, HR-10000 Zagreb, Croatia

* Correspondence: e-mail: mlandekic@sumfak.hr
Citation: ŠPORČIĆ M, LANDEKIĆ M, PAPA I, LEPOGLAVEC K, NEVEČEREL H, SELETKOVIĆ A, BAKARIĆ M 2017 Current Status and Perspectives of Forestry Entrepreneurship in Croatia. South-east Eur for 8 (1): 21-29. DOI: https://doi.org/10.15177/seefor.17-01

Received: 13 Dec 2016; Revised: 19 Jan 2017; Accepted: 24 Jan 2017; Published online: 18 Feb 2017

\begin{abstract}
Background and Purpose: The relevance and importance of forestry entrepreneurship is constantly increasing, especially in countries with high transition dynamics in forestry sector. In Croatia, forestry entrepreneurs have in short time become an indispensable part in the performing of harvesting and other types of forestry operations. This paper presents the current status and perspectives of forestry entrepreneurship in Croatia.

Materials and Methods: Based on the analysis of the available data from various sources (normative state acts, Forestry Chamber's official registries, databases and documents, state forestry company business reports etc.), this paper provides an overview of the legal and institutional framework for the activities of private entrepreneurs in Croatian forestry with particular attention to licensing forestry contractors and the role of the Croatian Chamber of Forest and Wood Technology Engineers (Forestry Chamber).

Results and Conclusions: The paper explains the activities, tasks, organization structure and formal bodies of the Forestry Chamber. The licensing model is also presented together with the formal criteria and minimum conditions which forestry entrepreneurs have to fulfill in order to acquire a license for forest work operations. Structural characteristics and the profile of forestry entrepreneurs is given by the number, size and type of business, the type of forest operations for which they are licensed, and the volume of work that they are performing for Croatian Forests Ltd, the state forest company. Finally, the paper includes some reflections on the perspectives and possibilities for improving the status of entrepreneurship in Croatian forestry.
\end{abstract}

Keywords: forestry entrepreneurship, contractors, licensing, forest work operations, Forestry Chamber, Croatia

\section{INTRODUCTION}

Due to the development of forestry technologies at the end of the $20^{\text {th }}$ century and structural changes within the sector (market transition, private restitution, etc.) a significant decrease in the number of employees and work machinery occurred in state-owned forestry companies. This period had also been characterized by the development of new business segments, such as the appearance and development of private contractors in forest harvesting [1-8]. The same scenario happened in Croatia with private contractors in the field of forestry operations during the 1990s. Research conducted in that period showed that in the beginning the first forest entrepreneurs were not adequately organized or qualified $[2,9,10]$. Conclusions from these papers showed that the newly introduced market mechanisms alone had not contributed to the profiling and selection of the best and most fitting forestry entrepreneurs. It also pointed out the necessity for developing a licensing model which would filter the existing forestry contractors and ensure quality in performing forest work operations [11].

Today private entrepreneurs play an important role in global forestry and also in Croatian forestry [12-19]. In Croatia they perform a significant amount of forest operations and 
provide various services (felling, hauling and skidding, transport, etc.) for their employers, mainly for Croatian Forests Ltd, the state forest management company. They have all also undergone a licensing process established in the meanwhile. The process of licensing has been given, as a special authority, to the Croatian Chamber of Forestry and Wood Technology Engineers.

This paper presents the current status of forestry entrepreneurship in Croatia. It provides an overview of the legal and institutional framework for the activities of private entrepreneurs in Croatian forestry with particular attention to licensing and the role of the Croatian Chamber of Forest and Wood Technology Engineers (Forestry Chamber). The paper explains the activities, tasks, organization structure and formal bodies of the Forestry Chamber. The licensing model is also presented together with the formal criteria and minimum conditions which forestry entrepreneurs have to fulfill in order to acquire a license for forest work operations. Structural characteristics and the profile of forestry entrepreneurs is given by the number, size and type of businesses, the type of forest operations for which they are licensed, and the volume of work that they are performing for the state company Croatian Forests Ltd. Finally, the paper includes some reflections on the perspectives and possibilities for improving the status of entrepreneurship in Croatian forestry.

\section{MATERIAL AND METHODS}

All data presented in this paper have been gathered from the Forestry Chamber's databases and official documents, as well as normative state acts and Croatian Forests Ltd. business reports. Organization and tasks of the Forestry Chamber are given based on the adopted regulations [20, 21], while the licensing model and structure of entrepreneurships (the number, size and type of licensed businesses) are defined according to respective legal documents and Forestry Chamber's public registries [22-25]. The scale of contractors' engagement in the state forestry is established by analyzing yearly business reports of the state forest company [26]. This includes overview of the volume of harvesting work (felling, skidding, forwarding and log transportation) that contractors are performing for the Croatian Forests Ltd. Analysed data are expressed in relative and absolute terms in the presented tables and graphs.

\section{Forest Resources in Croatia}

Total area encompassed by the General Forest Management Plan of the Republic of Croatia [27] covers 2.69 million (mill) ha, or $47 \%$ of country's land surface. The majority of forests are owned by the state $(78 \%$ or 2.11 mill ha), while only $22 \%$ (or 581,770 ha) is privately owned. Almost all of the state owned forests are managed by Croatian Forests Ltd., state forest management company (2.02 mill ha), while the rest ( 0.09 mill ha) is managed by other public institutions (Ministry of Defense, public institutions designated for the management of national parks and others).
Total growing stock of all forests is $398 \mathrm{mill} \mathrm{m}^{3}$, where 302 mill $\mathrm{m}^{3}$ is located in state forests managed by Croatian Forests Ltd., about 78 mill $\mathrm{m}^{3}$ is located in private forests, and 17 mill $\mathrm{m}^{3}$ in state forests managed by other public institutions.

Annual increment is 10.5 mill $\mathrm{m}^{3}$ (Croatian Forests Ltd. - 8 mill $\mathrm{m}^{3}$; private forests -2.1 mill $\mathrm{m}^{3}$; other state forests 0.4 mill $\left.\mathrm{m}^{3}\right)$. Annual felling amounts to 6.56 mill $\mathrm{m}^{3}$, out of which 5.8 mill $\mathrm{m}^{3}$ is located in state-owned forests managed by Croatian Forests Ltd., 0.7 mill $\mathrm{m}^{3}$ is located in private forests, and 0.06 mill $\mathrm{m}^{3}$ is located in other state-owned forests [27].

Basic principles of forest management in Croatia relate to balanced and multiple use of forests and to sustainability of their economical, ecological and social functions.

\section{RESULTS}

\section{Croatian Chamber of Forest and Wood Technology Engineers}

Croatian Chamber of Forest and Wood Technology Engineers, founded in 2006, is an autonomous and independent professional organization that performs the following tasks as entrusted public authorities:

- Keeps the registry of licensed engineers of Forestry and Wood Technology (Registry of authorised engineers);

- Issues, renews and revokes licenses (approvals) to legal and natural entities for conducting work operations in the field of forestry, hunting and wood technology;

- Determines the registration and membership fees for the Chamber;

- Determines professional obligations of the Chamber members and their performance in accordance with the code of professional ethics;

- Conducts professional exams for authorized engineers, according to a special regulation on the content and manner of taking professional exams passed by the Ministry in charge of forestry, hunting and wood technology;

- Performs other tasks that are by special laws established as a public authority of the Chamber.

Through its sections and committees (Figure 1), the Chamber also performs the following:

- Promotes the development of the profession and cares about professional training of members;

- Encourages the adoption of regulations that establish public authorities of the Chamber in accordance with the criteria of European and international practice;

- Represents the interests of its members;

- Provides expert opinions in the preparation of regulations in the field of forestry, hunting and wood technology;

- Organizes professional development of its members;

- Issues the Chamber's newsletter and other professional publications;

- Performs other duties in accordance with the law, the statute and other regulations of the Chamber. 


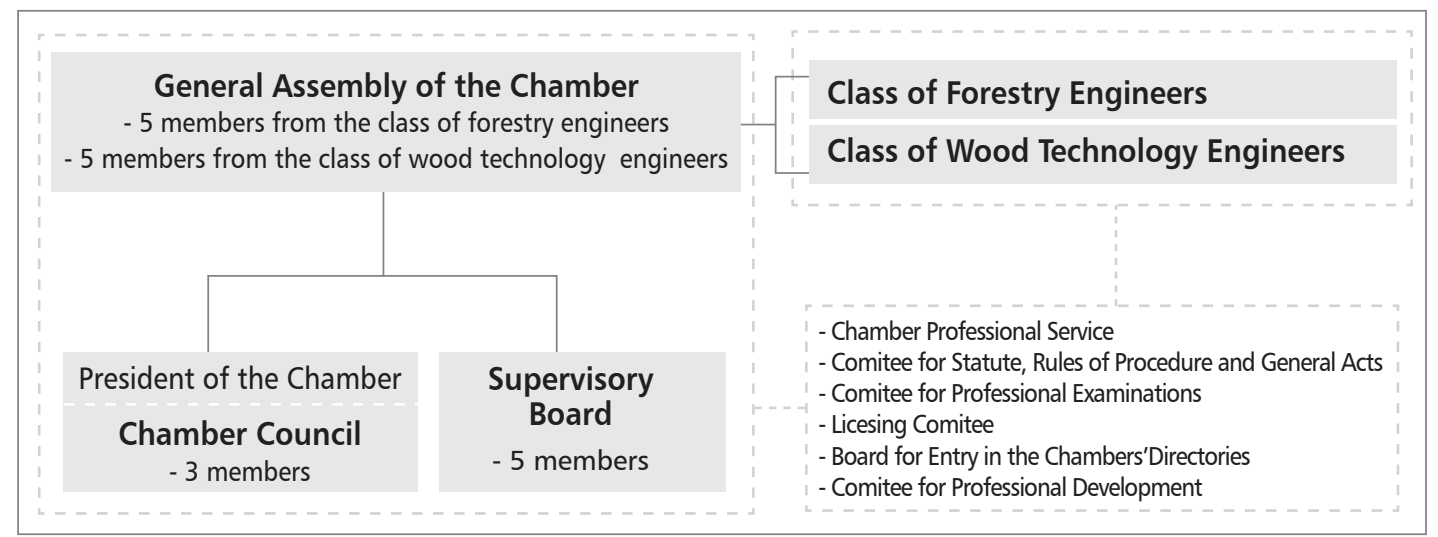

FIGURE 1. Organization of the Croatian Chamber of Forest and Wood Technology Engineers

The governing bodies of the Chamber are: General Assembly of the Chamber, Chamber Council, Supervisory Board and President of the Chamber (Figure 1). General Assembly is the highest governing body of the Chamber and it consists of elected representatives of two professional classes (the class of forestry engineers and the class of wood technology engineers). Chamber Council is the executive body of the Chamber and it consists of the Chamber President and presidents of two professional classes. Supervisory Board has a president and four members appointed and dismissed by the General Assembly. President of the Chamber is also the president of the Chamber Council and he or she is elected and dismissed by members of the General Assembly.

The Chamber today has 1198 active members. There are 1159 members from the class of forestry engineers and 39 members from the class of wood technology engineers.

\section{Licensing Model for Forest Entrepreneurs in Croatia}

The Law on Forests [28] prescribes that forest operations can be performed only by registered and licensed contractors, and professional activities by authorized engineers. Exceptionally, some less risky forest operations (work with simple manual tools related to habitat preparation, thinning, planting, reforestation) private forest owners can do on their own (or with the help from their household members and neighbors with no financial compensation).

The process of licensing forestry contractors is prescribed by the "Ordinance on issuing, renewal and revocation of the license for forestry, game management and wood processing operations". The Ordinance states expert and formal/general criteria which a forestry contractor has to present to the licensing committee: These include:

1. Evidence of legal personality, i.e. of its registration for performing forestry operations (excerpt from the court, professional or trade registry);

2. Evidence of the required number of employees (confirmation by the Croatian Pension Insurance Institute):

a. Proof on the number of workers,

b. Copy of the contract with authorised forestry engineer;

3. Evidence of procured machinery, equipment, measuring instruments and tools for performing certain type or stage of work for which a license is required (inventory list of fixed assets or a statement by the responsible person under the financial or penal responsibility, certified by a public notary);

4. Evidence of the professional qualifications of workers and certificates for:

a. Operators of work machinery and tools,

b. Forestry engineers authorised for the respective category of work (inclusion in the Registry of authorised engineers);

5. Evidence of certified functionality of machinery, equipment, measuring devices and tools needed for performing certain types and stages of forest work;

6. Documents from which annual costs and revenues of the entrepreneur for the previous year can be seen;

7. Other conditions prescribed by special legislative acts, depending on the type of license.

Types of forestry activities (in accordance with the "Ordinance on types of forestry operations, minimum conditions for their implementation and works that could be undertaken by forest owners independently" for which the entrepreneurs can request a license (single - for all work stages, or partial - for specific work stages) from the Chamber are presented in Table 1.

The Preparation stage includes:

- designing, planning and making surveys and studies,

- evaluation, analysis, assessment, observation and monitoring of the situation,

- selection of procedures, equipment, facilities, resources, materials, techniques and technologies of work,

- education and consultation.

The Performance stage includes direct execution of work.

The Supervision stage includes:

- control of quality and quantity of the conducted operations, procedures, equipment, facilities, resources, materials, applied techniques and technologies,

- control of quality and transport of forest products,

- making audits and reports

- issuance of certificates and other verifications of conformity with the prescribed standards and regulations. 
TABLE 1. The categories and stages of forest work for which Chamber issues a license

\begin{tabular}{|c|c|c|c|c|}
\hline & Category of forest work * & Preparation & Performance & Supervision \\
\hline 1. & $\begin{array}{l}\text { Development of forest management plans, game management plans and } \\
\text { programs for management of forest seed objects }\end{array}$ & & $\checkmark$ & \\
\hline 2. & Silvicultural work, forest reproduction material & $\checkmark$ & $\checkmark$ & $\checkmark$ \\
\hline 3. & Protection of forests against harmful organisms, fires and natural disasters & $\checkmark$ & $\checkmark$ & $\checkmark$ \\
\hline 4. & Harvesting operations & $\checkmark$ & $\checkmark$ & $\checkmark$ \\
\hline 5. & Construction and maintenance of forest infrastructure & $\checkmark$ & $\checkmark$ & $\checkmark$ \\
\hline 6. & Urban forestry & $\checkmark$ & $\checkmark$ & $\checkmark$ \\
\hline 7. & Forest ecology and preservation of biodiversity & & $\checkmark$ & \\
\hline 8. & Tree marking & $\checkmark$ & $\checkmark$ & $\checkmark$ \\
\hline 9. & Management of private forests & & $\checkmark$ & \\
\hline
\end{tabular}

*For activities 1, 7 and 9 a single license is issued, and for other types of activities a partial license can be issued (for preparation, for performing and for supervising the activitv)

Stated forestry activities (Table 1) may be performed only by contractors who meet the minimum requirements for carrying out forest work and who have passed the licensing procedure (applied for license with all necessary documents and received a positive evaluation of the Chamber's licensing committee). Minimum requirements for performing forest operations include meeting the prescribed conditions of professional and technical proficiency. Professional requirements are met if all employees of the contractor (the licensee) are employed on a full-time basis in their positions. Technical requirements are met if the contractor (license holder) has the machinery, equipment, devices and tools necessary for technologically appropriate execution of work. This includes safety and protection equipment for workers and all persons who are permanently or temporarily located at the site.

Minimum requirements are defined separately for every category (and stage) of forest work. Table 2 shows the minimum requirements for contractors engaged in harvesting operations as the most common license category.

Licenses for forest contractors are issued for a period of five years. Upon the end of license validity, contractor can make a request for license renewal. The request is, same as the first issuing of license, submitted to the Committee of the Chamber, together with the documented proofs about the fulfillment of respective conditions.

\section{Forestry Entrepreneurs - Structure and Characteristics}

The process of licensing of private entrepreneurs in Croatian forestry began in October 2007. Until today 940 licenses have been issued (the state on $25^{\text {th }}$ April 2016). Among them 356 licenses (37.9\%) are active and 584 (62.1\%) have been revoked for different reasons (Table 3 ).

Out of 356 active licenses, i.e. companies that possess complete or partial license for at least one of the nine types of forestry operations, 220 of them $(61.8 \%$ of all active companies) are registered as sole proprietorships. Around 112 active license holders (31.5\%) are registered as limited companies (Ltd). Public institutions and other types of organizations (joint-stock company, limited partnership, family farm, cooperative) account for 24 (6.7\%) active licenses (Figure 2).

Territorial distribution of the contractors, according to the company's headquarters, shows that the majority of

TABLE 2. Minimal requirements for contractors engaged in 'harvesting operations'

\begin{tabular}{|c|c|}
\hline $\begin{array}{l}\text { Harvesting } \\
\text { operations }\end{array}$ & Requirements \\
\hline Preparation & - 1 authorised forestry engineer (per every $10,000 \mathrm{~m}^{3}$ of gross volume) \\
\hline Performance & $\begin{array}{l}\text { - For the production of up to } 8000 \mathrm{~m}^{3} \text { of net volume per year - } 1 \text { forestry technician; } \\
\text { - For the production level of } 8000 \text { to } 30,000 \mathrm{~m}^{3} \text { of net volume per year - } 1 \text { authorized forestry engineer and } 1 \text { forestry } \\
\text { - } \quad \text { Fochnician; } \\
\text { forestry engineer and one forestry technician; } \\
\text { - } \quad \text { Minimum of } 2 \text { workers per working group } \\
\text { - } \quad \text { Specific work machinery, tools and equipment } \\
\text { - } \quad \text { Attests for work machinery and tools } \\
\text { - Evidence of the technical condition and working order of machines and tools } \\
\text { - Evidence of professional qualifications for workers handling working tools (only for chain saw, power tools and } \\
\text { - } \quad \text { machinery) } \\
\text { *Animal extraction does not require employment of authorised forestry engineer or forestry technician, regardless of the } \\
\text { level of production. }\end{array}$ \\
\hline Supervision & 1 authorised forestry engineer (per every $20,000 \mathrm{~m}^{3}$ of gross volume) \\
\hline
\end{tabular}


entrepreneurs are located in central Croatia, Gorski Kotar and Lika region, i.e. in the hilly-mountainous part of Croatia. A somewhat smaller number of contractors are situated in Slavonia and northern Croatia, while in Istria and Dalmatia there are just a few contracting businesses. Individually, the highest number of active entrepreneurs is in PrimorjeGorski Kotar County (12.9\%), Lika-Senj County (12.4\%) and Karlovac County (11\%) (Figure 3). Different concentration of contractors in some areas is the result of the quantity and type of forest work for which employers (mainly Croatian Forests Ltd.) hire them. Complexity of working conditions and the tradition of engagement in forestry are also important influence factors [10]. It should be noted that two license

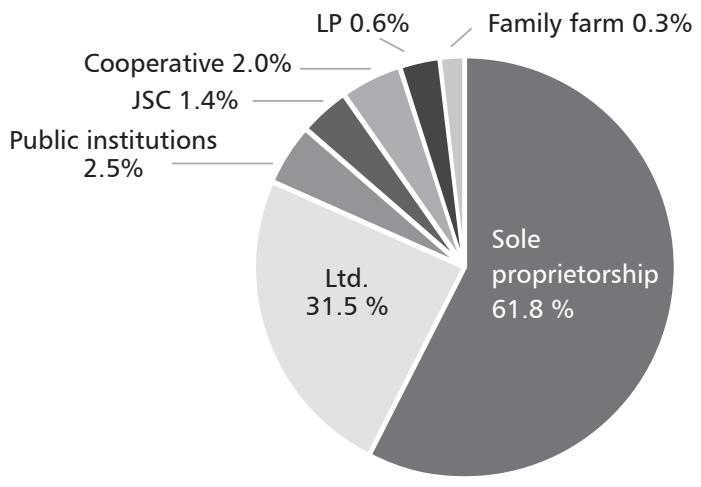

FIGURE 2. Types of businesses licensed for conducting forest operations (the state on 25th April 2016) holders are from Slovenia and two from Austria.

Considering the number of entrepreneurs licensed for certain forestry activities, the largest share is made up of contractors with license (complete or partial) for harvesting operations (84.6\% of all active companies) (Figure 4). Considerable proportion of companies are also licensed for activities related to silviculture, forest seed and seedlings (53.4\% of active companies), where majority of licenses refers to silvicultural operations (171 licenses) and very rarely to operations concerning forest seeds and seedlings. Entrepreneurs licensed for other forest activities are also scarce with a slightly higher number of licenses recorded for construction and maintenance of forest infrastructure (18.3\%) and tree marking (13.2\%) (Figure 4).

The number and type of services that forestry contractors provide is usually limited to one type of forestry activity. Only three organizations (0.8\%) possess licenses in all 9 categories of forest work, according to the "Ordinance on types of forestry operations, minimum conditions for their implementation and works that could be undertaken by forest owners independently" [22]. Three companies possess licenses for 8 different types of forest work, and two companies have licenses for 7 different forestry activities. The majority of entrepreneurs possesses a license only in one category of forest work (161 companies, i.e. $45.2 \%$ ), or perhaps in two different categories (124 companies, i.e. 34.8\%). The most frequent combinations of licenses, i.e. the number and type of forestry activities for whose implementation entrepreneurs have been licensed, are shown in Table 4.

Considering that harvesting operations represent the most common license category, the structure of contractors

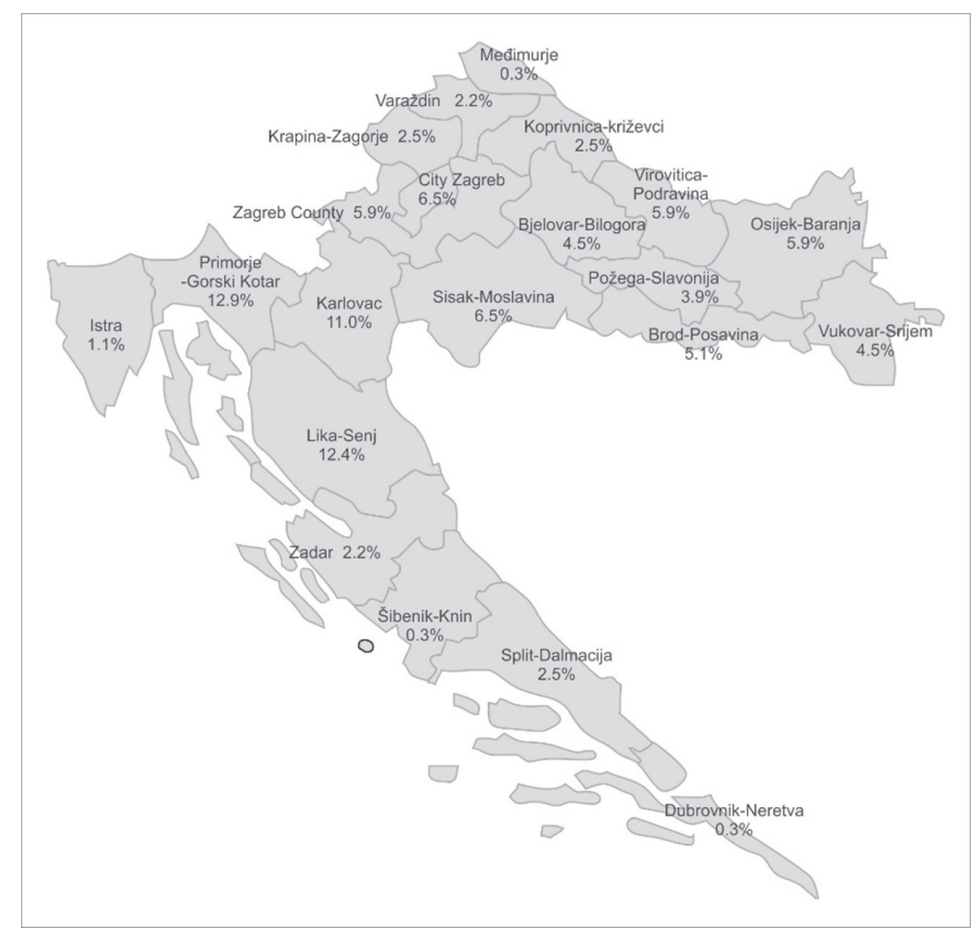

FIGURE 3. The distribution of forestry entrepreneurs by counties 
TABLE 3. Revoked licenses for conducting forest operations

\begin{tabular}{lcc}
\hline \multicolumn{1}{c}{ Reason for revoking the license } & $\mathrm{N}$ & $\%$ \\
\hline Renewal, change or extension of license & 216 & 37.0 \\
Not complying with the requirements prescribed by the Ordinance on issuance of licenses & 208 & 35.6 \\
Expired license & 89 & 15.2 \\
Termination of business, request for license withdrawal or canceling license application & 59 & 10.1 \\
Other reasons & 12 & 2.1 \\
\hline
\end{tabular}

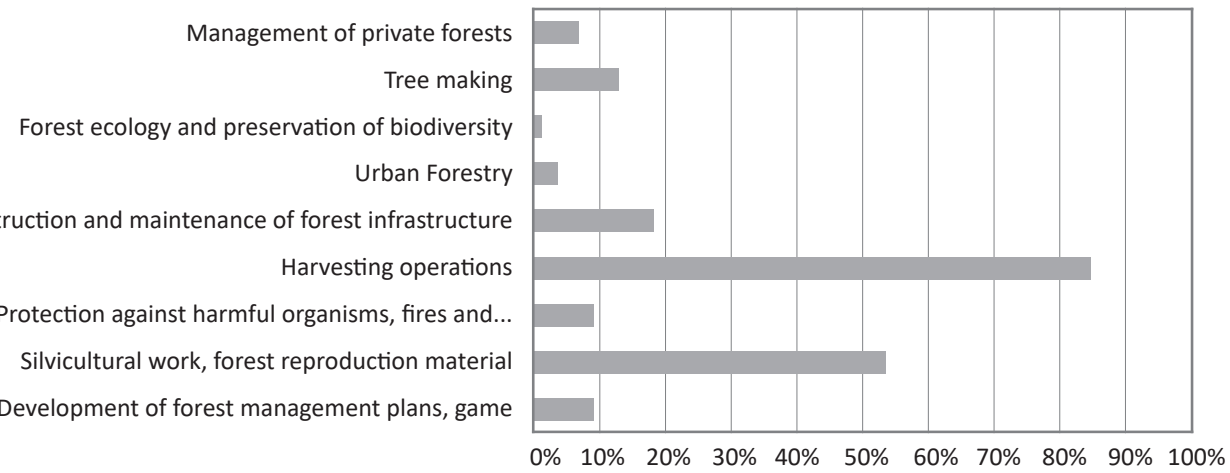

FIGURE 4. The share and number of active license holders by the type of forest activities (the state on 25th April 2016)

engaged in harvesting activities has been analyzed in more detail (Table 5). Complete license (for Preparation, Performance and Supervision stage) is owned by 11 companies. All other companies possess partial licenses, mostly for the Performance stage of harvesting operations (284 licenses altogether). Partial license for Preparation and Supervision stages (without Performance stage) is owned by 16 companies, and only one company possesses a license solely for Supervision stage.

The highest proportion of contractors, in all three stages, meets only the minimum requirements prescribed by the "Ordinance on types of forestry operations, minimum conditions for their implementation and works that could be undertaken by forest owners independently". Accordingly they possess licenses for the lowest volume of harvesting activities.
These are:

- 17 companies (63.0\%) in Preparation stage licensed for up to $10,000 \mathrm{~m}^{3}$ of gross volume,

- 222 companies (78.2\%) in Performance stage licensed for up to $8000 \mathrm{~m}^{3}$ of net volume per year,

- 18 companies (64.3\%) in Supervision stage licensed for up to $20,000 \mathrm{~m}^{3}$ of gross volume.

Even though forestry contractors in Croatia predominantly represent small, modestly equipped businesses, which is evident from the number of licenses for the lowest volume harvesting activities, during the past few years they have conducted a significant share of harvesting operations in state forestry (Figure 5-7).

On average, each year forestry contractors perform around $26 \%$ of all felling activities in state forests. Their

TABLE 4. The number and type of services (activities) for which forestry contractors simultaneously possess a license (state on 25th April 2016)

\begin{tabular}{|c|c|c|}
\hline \multirow{2}{*}{ Forest work } & \multicolumn{2}{|c|}{ Number of companies } \\
\hline & $\mathrm{N}$ & $\%$ \\
\hline 2) Silvicultural work, forest reproduction material, and 4) Harvesting operations & 115 & 32.3 \\
\hline 4) Harvesting operations & 113 & 31.7 \\
\hline 5) Construction and maintenance of forest infrastructure & 27 & 7.6 \\
\hline 1) Development of forest management and hunting plans & 16 & 4.5 \\
\hline 2) Silvicultural work, forest reproduction material, 4) Harvesting operations, and 8) Tree marking & 9 & 2.5 \\
\hline $\begin{array}{l}\text { 1) Development of forest management and hunting plans, 2) Silvicultural work, forest reproduction } \\
\text { material, 3) Protection of forests, 4) Harvesting operations, 8) Tree marking, and 9) Management of } \\
\text { private forests }\end{array}$ & 6 & 1.7 \\
\hline Other 27 different combinations & 56 & 15.7 \\
\hline
\end{tabular}


TABLE 5. The structure of forestry entrepreneurs licensed for harvesting operations (the state on 25th April 2016)

\begin{tabular}{|c|c|c|c|c|}
\hline \multirow{2}{*}{ Stage } & \multirow{2}{*}{ Volume of work } & \multicolumn{3}{|c|}{ Number of companies } \\
\hline & & $\mathrm{N}$ & & $\%$ \\
\hline \multirow{4}{*}{ Preparation } & Up to $10,000 \mathrm{~m}^{3}$ of gross volume & 17 & \multirow{4}{*}{27} & \multirow{4}{*}{7.96} \\
\hline & Up to $20,000 \mathrm{~m}^{3}$ of gross volume & 5 & & \\
\hline & Up to $50,000 \mathrm{~m}^{3}$ of gross volume & 1 & & \\
\hline & Without limitations & 4 & & \\
\hline \multirow{6}{*}{ Performance } & Up to $8000 \mathrm{~m}^{3}$ of net volume per year & 222 & \multirow{6}{*}{284} & \multirow{6}{*}{83.82} \\
\hline & Up to $30,000 \mathrm{~m}^{3}$ of net volume per year & 17 & & \\
\hline & Up to $60,000 \mathrm{~m}^{3}$ of net volume per year & 1 & & \\
\hline & Up to $120,000 \mathrm{~m}^{3}$ of net volume per year & 2 & & \\
\hline & Up to $180,000 \mathrm{~m}^{3}$ of net volume per year & 1 & & \\
\hline & Without limitations & 41 & & \\
\hline \multirow{5}{*}{ Supervision } & Up to $20,000 \mathrm{~m}^{3}$ of gross volume & 18 & \multirow{4}{*}{28} & \multirow{4}{*}{8.26} \\
\hline & Up to $40,000 \mathrm{~m}^{3}$ of gross volume & 5 & & \\
\hline & Up to $100,000 \mathrm{~m}^{3}$ of gross volume & 1 & & \\
\hline & Without limitations & 4 & & \\
\hline & Licenses altogether & 339 & & 100.00 \\
\hline
\end{tabular}

share in skidding and forwarding has been notable for longer time now, and in the last five years it amounted to $40.6 \%$. In log transportation $81.9 \%$ of removal is done by forestry contractors [26]. In private forests the activity of contractors is not documented, so there is no exact data about their operations there.

\section{DISCUSSION AND CONCLUSSIONS}

Private entrepreneurs in forestry today play an important role in all forms of forest ownership and management regimes, both on the European and global scale. In Croatia, they have in short time become an indispensable part in performing harvesting and other types of forestry operations. The biggest user of their services is Croatian Forests Ltd, the state forest management company, for which forestry contractors every year on average conduct $26 \%$ of felling, $41 \%$ of skidding and $82 \%$ of log transportation. The volume of work that they perform in private forests is significantly smaller, due to poor management of private forests and the possibility for forest owners to perform part of the work (less risky forestry operations) on their own.

Forestry entrepreneurs have undergone a licensing process established in 2007 with the foundation of the Croatian Chamber of Forest and Wood Technology Engineers and the adoption of necessary regulations ("Ordinance on types of forestry operations, minimum conditions for their implementation and works that could be undertaken by forest owners independently"; "Ordinance on issuing, renewal and revocation of the license for forestry, game management and wood processing operations") $[22,23]$. The process of licensing forestry entrepreneurs is an important element of entrepreneurial frame in every activity, and in the field

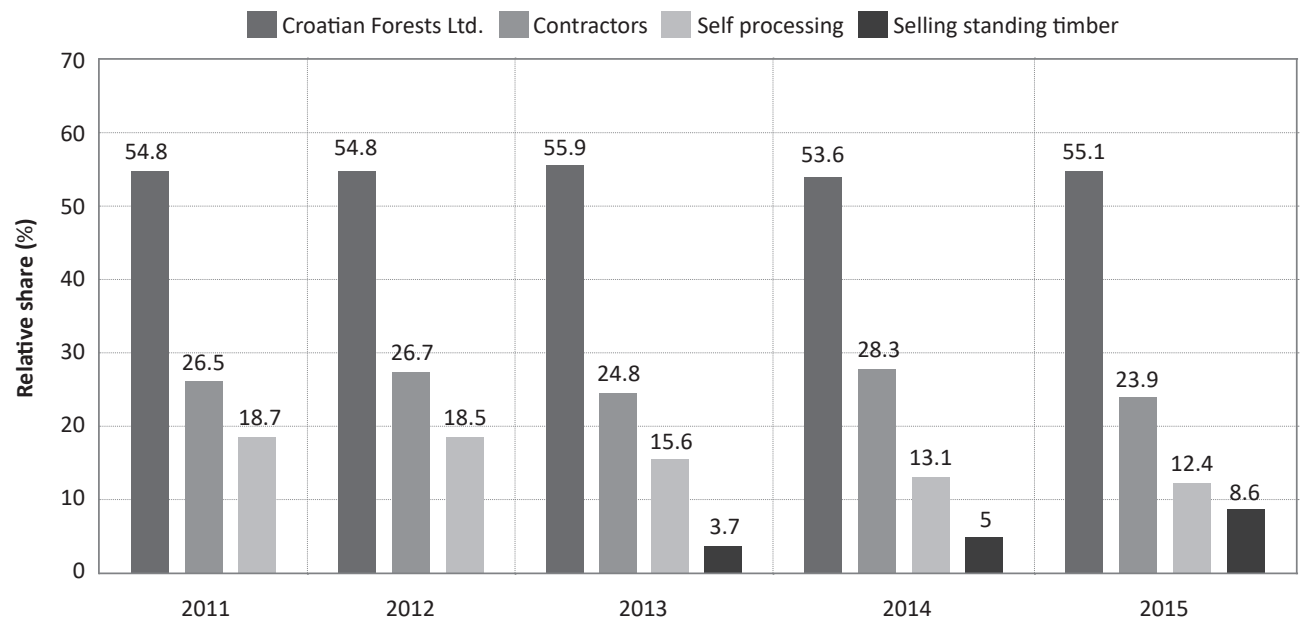

FIGURE 5. The share of contractors in felling activities by years 
Croatian Forests Ltd. Contractors

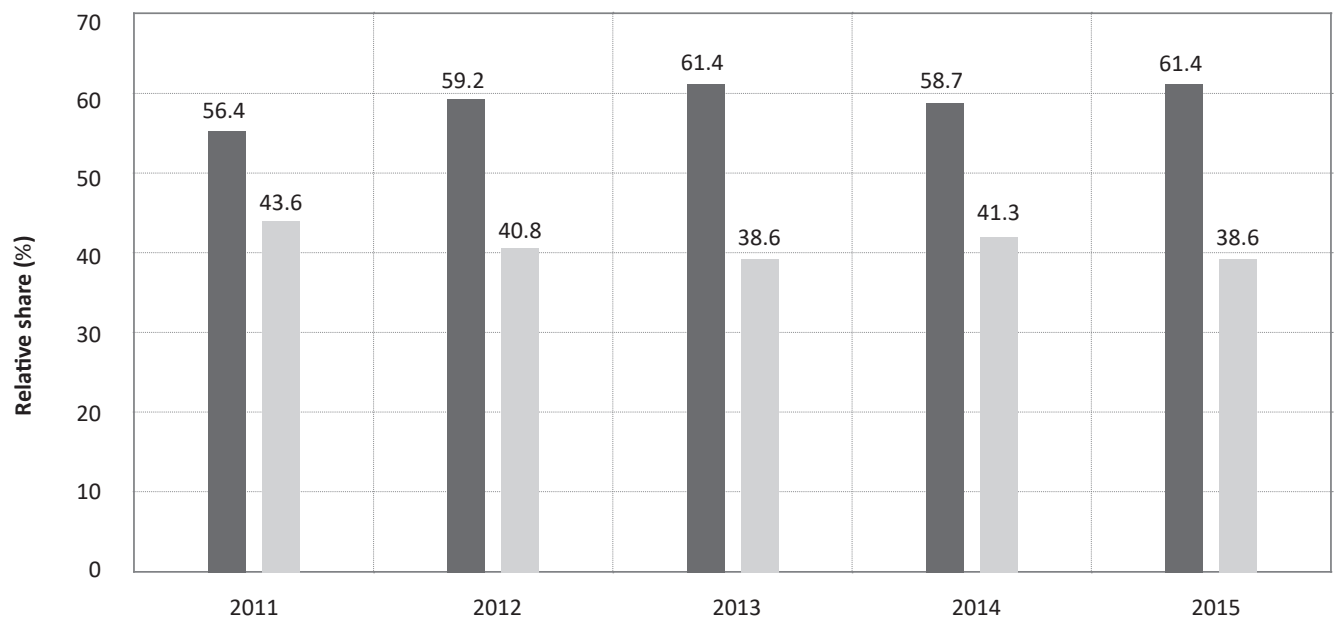

FIGURE 6. The share of contractors in skidding and forwarding activities by years

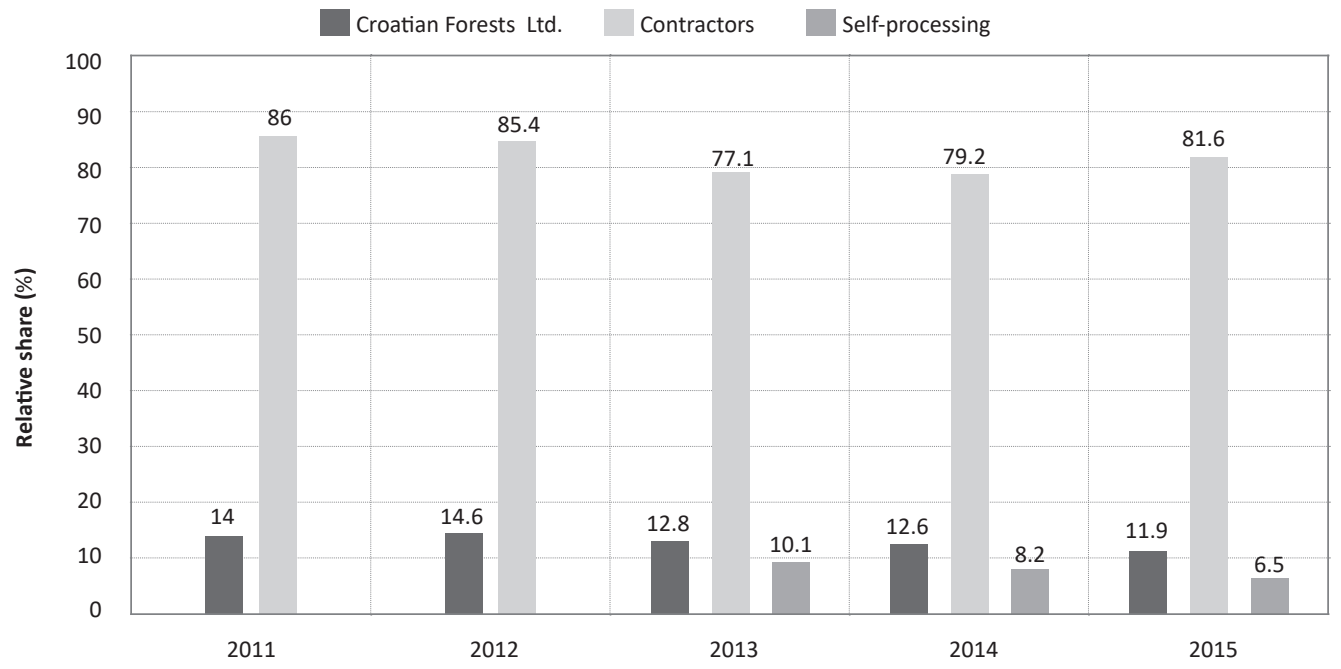

FIGURE 7. The share of contractors in log transportation by years

of forestry it also represents an unconditional contingency of sustainable forest management. The licensing process puts an emphasis on the inclusion of private entrepreneurs in the sustainable forest management through a process of certification of their quantitative and qualitative characteristics.

The foundation of the Chamber as an institution with public authority and implementation of the licensing process have certainly improved the status of forestry entrepreneurship in Croatia, but in the meanwhile, new challenges and problems have arisen. Some of the open issues related to the Chamber, licensing, authorized engineers and the like are the following:

- the issue of the operational supervision and control of the contractors' performance and quality of work - the Chamber doesn't have developed instruments for it,

- the set limit for employing authorized forestry engineers in Performance stage of harvesting operations $\left(30,000 \mathrm{~m}^{3}\right.$ of net volume per year) receives many critics from contractors which suggests a need for reevaluation,

- the problem of issuing certificates (official signet) to authorized forestry engineers on their own behalf, or as so far, on the behalf of the company that employs them,

- the Chamber is given the task of issuing tree marking hammer to contractors (with adequate license) acquired authority which needs to be regulated in respective acts of the Chamber,

- equal representation of two professional classes (forestry engineers and wood technology engineers) in governing bodies of the Chamber (General Assembly), i.e. in decision making, despite the different number of members,

- the issue of certifying forestry engineers for operations concerning urban forestry, landscaping and horticultural 
activities, and the relation with the Croatian Chamber of Architects which authorises 'landscape architects'.

All these, and some other issues require adequate attention and solutions that will further enhance the situation of forestry entrepreneurship in Croatia. One of the important influencing factors is certainly the common European labor market and free flow of labor force, as a promising opportunity for expanding entrepreneurs' activities. In addition, based on the findings on the current state and development of entrepreneurship, the perspectives of Croatian forestry entrepreneurs also depend upon:

- Restructuring of the state forest management company, with which many diversified entrepreneurial opportunities should be created;

- Continual development and strengthening of the system and the criteria for licensing forestry entrepreneurs;

- Intensity and strictness of the implementation of measures related to education, training, occupational health and safety of forestry workers employed in private forestry sector;

- Development of entrepreneurial spirit in existing and future forestry businesses, through education and information dissemination, i.e. the promotion of models for transfer of (tacit) knowledge;

- State financial policy related to the promotion of national entrepreneurial activities through subventions, tax deductions, credit arrangements and other incentives, all with the goal of raising the level of technical, technological, professional, personnel and other competencies of forestry entrepreneurs.

\section{REFERENCES}

1. MÄKINEN P 1997 Success factors for forest machine entrepreneurs. Journal of Forest Engineering 8 (2): 27-37

2. MARTINIĆ I 1998 Stanje i razvoj izvođenja šumskih radova u Hrvatskoj neovisnim poduzetnicima. Mehanizacija šumarstva 23 (1): 7-15

3. GROSSE W 2000 Emergence of forest service enterprises in east German 'Lander'. Mehanizacija šumarstva 25 (1-2): 2941.

4. POSCHEN P 2000 Contract labour in European forestry. In: Proceedings of $1^{\text {st }}$ European Forest Entrepreneurs' Day. 16 September 2000, Celle, Germany, pp 12-14

5. JAAKOLA S 2002 The situation of contract labour in Nordic countries. In: Proceedings of $3^{\text {rd }}$ European Forest Entrepreneurs' Day. 29 September 2002, Edinburgh, Scotland, $5 p$

6. KASTENHOLZ E 2002 Best practices in forestry contracting. Forworknet Update, December 2002, 3 p

7. ŠPORČIĆ M 2005 Insight into some aspects of entrepreneurship in the European forestry. Sumar list 129 (5-6): 287-298

8. ŠALKA J, LONGAUER R, LACKO M 2006 The effects of property transformation on forestry entrepreneurship and innovation in the context of Slovakia. Forest Policy Econ 8 (7): 716-724. DOI: https://doi.org/10.1016/i.forpol.2005.06.017

9. VONDRA V, MARTINIĆ I, ZDJELAR M 1997 Procjena uzroka nerazvijenosti privatnog poduzetništva u šumarskom gospodarstvu Hrvatske. Studija, Zavod za istraživanja u šumarstvu, Šumarski fakultet Sveučilišta u Zagrebu, Zagreb, Croatia, pp 1-14

10. ŠPORČIĆ M, MARTINIĆ I 2004 Forest contractors in Croatia. Sumar list 128 (11-12): 633-648

11. ŠPORČIĆ M, MARTINIĆ I 2005 A model for licensing forest contractors. Sumar list 129 (7-8): 375-385

12. ŠPORČIĆ M MARTINIĆ I, LANDEKIĆ M, LOVRIĆ M, SVAKIDAN M 2009 Overview of entrepreneurship in forestry of Central and Eastern Europe. Nova mehanizacija šumarstva 30: 36-46

13. DROLET S, LEBEL L 2010 Forest harvesting entrepreneurs, perception of their business status and its influence on performance evaluation. Forest Policy Econ 12 (4): 287-298. DOI: https://doi.org/10.1016/i.forpol.2009.11.004

14. HÄGGSTRÖOM C, KAWASAKI A, LIDESTAV G 2013 Profiles of forestry contractors and development of the forestrycontracting sector in Sweden. Scand J Forest Res 28 (4): 395404. DOI: https://doi.org/10.1080/02827581.2012.738826
15. MALINEN J, NOUSIANEN V, PALOJARVI K, PALANDER T 2014 Prospects and challenges of timber trucking in a changing operational environment in Finland. Croat J For Eng 35 (1): 91-100

16. CRNIĆ | 2015 Examples of best practice in contract labour in forestry. Undergraduate thesis, Faculty of Forestry, University of Zagreb, Zagreb, Croatia, $30 \mathrm{p}$

17. SPINELLI R, VISSER R, THEES O, SAUTER UH, KRAJNC N, RIOND C, MAGAGNOTTI N 2015 Cable logging contract rates in the alps: the effect of regional variability and technical constraints. Croat J For Eng 36 (2): 195-203

18. ST-JEAN E, LEBEL L 2015 Forestry entrepreneurs - research on high performance business model. In: Zlatic M (ed) Precious Forests - Precious Earth. Intech, Rijeka, Croatia, pp 185-198

19. MARENČE J, KRČ J 2016 Possibilities of using small tractors for forestry operations on private property. Croat J For Eng 37 (1): 151-162

20. OFFICIAL GAZETTE 2006 Law on Croatian Chamber of Forestry and Wood Processing Industry Engineers. Official Gazette of the Republic of Croatia, No. 22/06

21. OFFICIAL GAZETTE 2007 Statute of Croatian Chamber of Forestry and Wood Processing Industry Engineers. Official Gazette of the Republic of Croatia, No. 136/06, 61/07.

22. OFFICIAL GAZETTE 2015 Ordinance on types of forestry operations, minimum conditions for their implementation and works that could be undertaken by forest owners independently. Official Gazette of the Republic of Croatia, No. $16 / 15$

23. CROATIAN CHAMBER OF FORESTRY AND WOOD PROCESSING INDUSTRY ENGINEERS 2015 Ordinance on issuing, renewal and revocation of the license for forestry, game management and wood processing operations. Zagreb, $8 \mathrm{p}$

24. CROATIAN CHAMBER OF FORESTRY AND WOOD PROCESSING INDUSTRY ENGINEERS 2016a Registry of licensed forestry entrepreneurs

25. CROATIAN CHAMBER OF FORESTRY AND WOOD PROCESSING INDUSTRY ENGINEERS 2016b Registry of authorised forestry and wood technology engineers

26. CROATIAN FORESTS LTD 2001-2015 Business Reports for the years 2011-2015

27. MINISTRY OF AGRICULTURE 2005 General forest management plan of the Republic of Croatia for period 2005-2016

28. OFFICIAL GAZETTE 2014 Law on Forests. Official Gazette of the Republic of Croatia, No. 140/05, 82/06, 129/08, 80/10, $124 / 10,145 / 11,25 / 12,68 / 12,94 / 14$ 
